\title{
Origins of...
}

\section{Image analysis in clinical pathology}

\author{
G A Meijer, J A M Beliën, P J van Diest, J P A Baak
}

The term "image analysis" is reserved for a special discipline in pathology that aims to obtain diagnostically important information in an objective and reproducible manner, by measuring and counting. The origins of measuring microscopical images are almost as old as the microscope itself. Leeuwenhoek (fig 1) in the 17 th century had developed a system to measure microscopic objects. As a reference he used sand grains of different sizes, and hairs from his head, beard or wig. ${ }^{12}$ Using this method, in 1674 he measured human erythrocytes as 25000 times smaller than a small sand grain, corresponding to $8.5 \mu \mathrm{m} .^{3}$ Given the means at his disposal, this is amazingly precise.

This review intends to give an overview of the developments that have led to image analysis as it is currently applied in routine diagnostic cytopathology and histopathology as well as in research. For the purpose of clarity we discriminate between three different areas of image analysis; however, they are not mutually exclusive. These areas are measuring morphological characteristics of tissues, cells, nuclei or even nucleoli; counting of cell or tissue components; and cytometry and pattern recognition, which aims to measure cytochemical, histochemical, and molecular cell or tissue features

Department of
Pathology, Academisch
Ziekenhuis Vrije
Universiteit,
Amsterdam, The
Netherlands
Correspondence to:
Dr G A Meijer, Department
of Pathology, VU Hospital,
PO Box 7057, 1007 MB
Amsterdam, The
Netherlands. e-mail:
ga.meijer@azvu.nl
Accepted for publication
25 February 1997

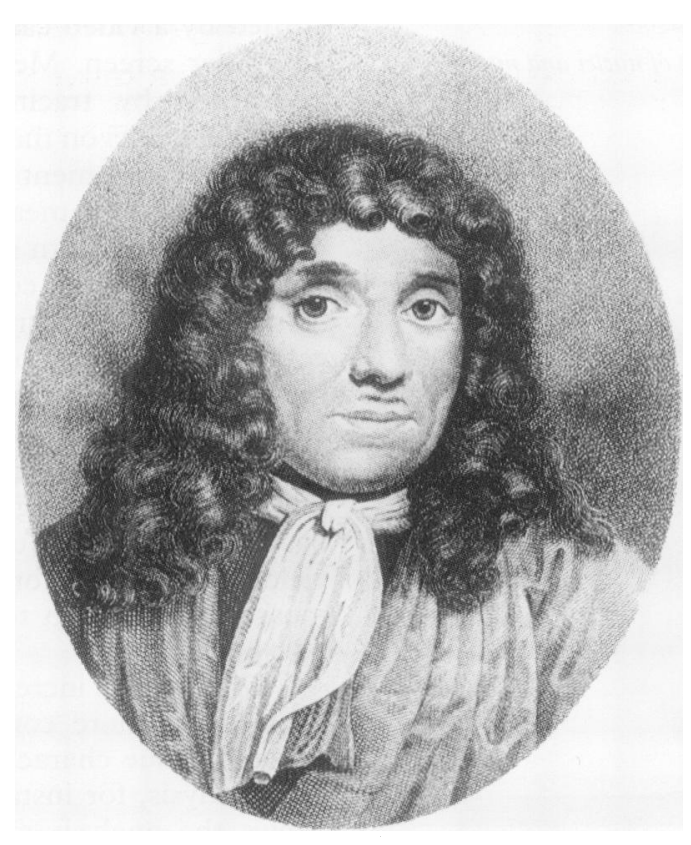

Figure 1 Antoni van Leuwenhoek (1632-1723) in the 17 th century had developed a system for measuring microscopic objects. (Courtesy the Antoni van Leeuwenhoek Hospital, Amsterdam.) such as the DNA content of nuclei, and to classify cells according to the distribution pattern of these features in cells or nuclei.

\section{Morphometry}

Morphometry is the quantitative description of geometric features of structures of any dimension. ${ }^{4}$ This includes planimetry, which refers to the measurement of geometric features of structures in two dimensions. Stereology denotes all techniques used to obtain quantitative information about geometric features of structures with a test system of lower dimension than the structure itself-for example, point or line grids.

Measuring requires a reference or a probe. In 1777, Georges Louis Leclerc, Comte de Buffon, demonstrated that the chance that a needle of given length (a probe) dropped at random on a series of equidistal parallel lines would intersect one of these lines, depended on the distance between the lines. ${ }^{5}$ The concept of measuring distances by randomly dropping a probe was the cradle of stereology. In general, stereological techniques can be used to estimate fractions of different tissue components, inner and outer surface density, shape and volume. Delesse, a French geologist, in 1847 measured areas of different compartments in the microscopical images of random cross sections of rock, and demonstrated that the areas occupied by each compartment were exactly proportional to the volume fraction of each compartment in the rock. ${ }^{6}$ The first assessments of volume fraction were performed by cutting the different areas from a drawing on paper and by determining the total weight of paper occupied by each compartment. In 1898, Rosiwal showed that the same information could be obtained by taking the ratio of the total length of test lines overlying each compartment. ${ }^{7}$ A further improvement in the estimation of volume fraction was initiated by the Russian petrographer Glagolev, and further developed by the American physiologist Chalkey, who was one of the first to apply the method to histological images. ${ }^{89}$ They showed that volume fractions of different compartments could be assessed from the ratio of the sum of points falling on each of these compartments. This sequence of dimension reductions is a key feature of stereology (fig 2). An authoritative discussion of the application of this, and more advanced stereological methods in histology, was presented by Weibel. ${ }^{10}$ Among 

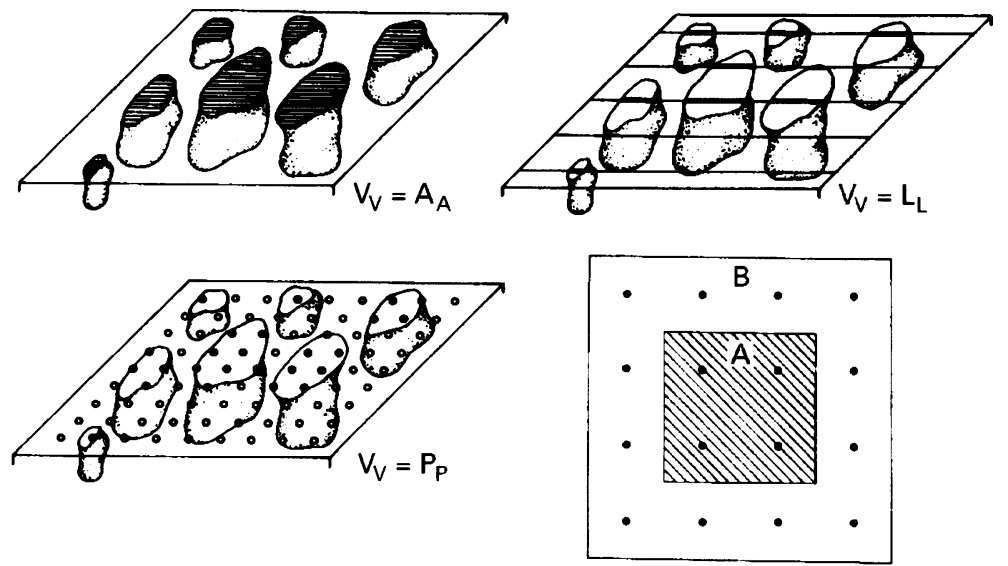

Figure 2 Estimation of volume fraction by determining area fractions $\left(V_{V}=A_{A}\right)$, line length fraction $\left(V_{V}=L_{L}\right)$, and point counting fractions $\left(V_{V}=P_{R}\right)$. The proportion of points falling on the hedged square (4 of 16) is proportional to the area occupied by the hedged square (that is $25 \%$ of the large square). (After Bouw, $1975^{59}$.)

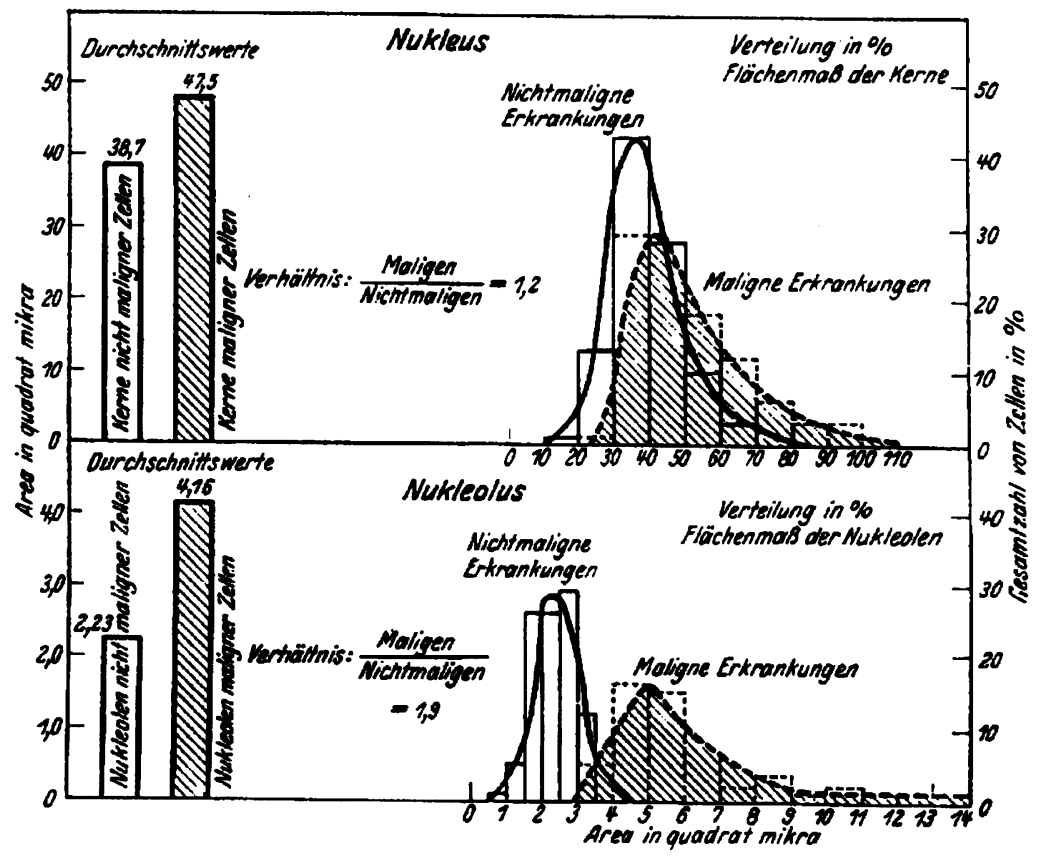

Figure 3 Results of the study by Haumeder in 1933 of the size of nuclei and nucleoli in malignant and non-malignant breast tissue.

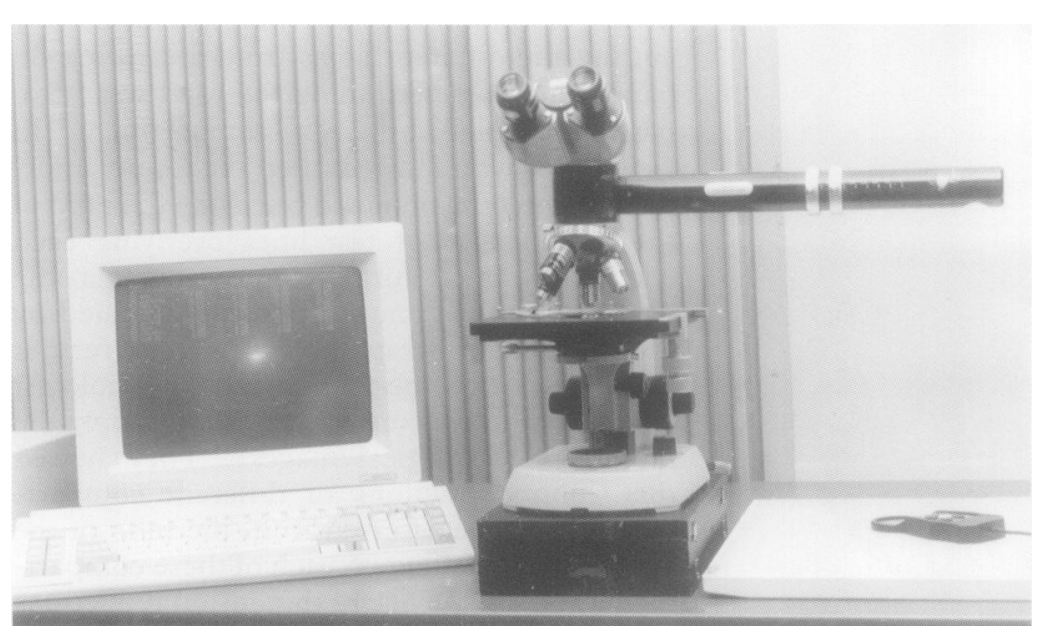

Figure 4 In the early 1980s, graphic tablets connected to a computer allowed for easy measuring of the area of tissue components, either from microphotographs or by projecting a pinpoint light from the cursor of the graphic tablet through a drawing tube into the microscopical image. the more recent advances in stereology is the assessment of the volume-weighted mean volume of particles of arbitrary shape such as nuclei by measuring the length of random intercepts. ${ }^{11}$

Planimetry, or the measurement of geometric features of structures in the twodimensional microscopical image is a more direct approach. The French microscopist Donné, who was among the first to study human cells microscopically, introduced a $2.5 \mu \mathrm{m}$ micrometer to measure microscopic objects. He also was the first to use microphotographs, applying the Daguerreotype technique. ${ }^{12}$ During many decades to follow, the two approaches to measure microscopical images were either to use a measuring ocular or an ocular grid and measure through the microscope, or to take microphotographs or make drawings using a camera lucida, and then perform measurements on the prints or drawings.

Using these methods, Jacobj in 1925 came to the conclusion that the size of cells doubles before mitosis. ${ }^{13}$ The German pathologists Haumeder, Schairer, and Ehrich, based on their measurements, were the first to point at the increased size of nuclei and nucleoli in tumours compared with normal tissue (fig 3). ${ }^{14-16}$

From the 1970 s on, computers became more generally available. Graphic tablets connected to a computer allowed for easy measurement of the area of cellular or tissue components, either from microphotographs or by projecting a pinpoint light from the cursor of the graphic tablet through a drawing tube into the microscopical image, allowing tracing of-for example, nuclei (fig 4). From these tracings, not only could nuclear areas easily be computed but also information could be obtained about the shape of nuclei. When video cameras became widely available in the $1980 \mathrm{~s}$, these systems were further improved. With modern morphometry equipment, the microscopical image is recorded by a video camera and displayed on a computer screen. Measurements can then be performed by tracing the outlines of-for example, nuclei on the screen and the precision of each measurement can be appreciated.

The palette of measurements was continuously extended from simple measurements on objects to more contextual analysis. For instance, by measuring the distance from the centre of gravity of nuclei to the basal membrane and the epithelial surface, stratification of nuclei in-for example, dysplastic epithelium, could be quantified. In addition, the angle of the longest axis of nuclei to the basal membrane could be measured which yields a measure for loss of polarity. Such measurements help to objectify and quantify "dysplasia".

Moreover, the increased power of computers allowed for more complicated evaluations of cell and tissue characteristics. Syntactic structure analysis, for instance, is a technique that allows the analysis and measurement of the relations of tissue objects to each other-for example, the minimum spanning tree and Voronoi's tessellation (fig 5). 

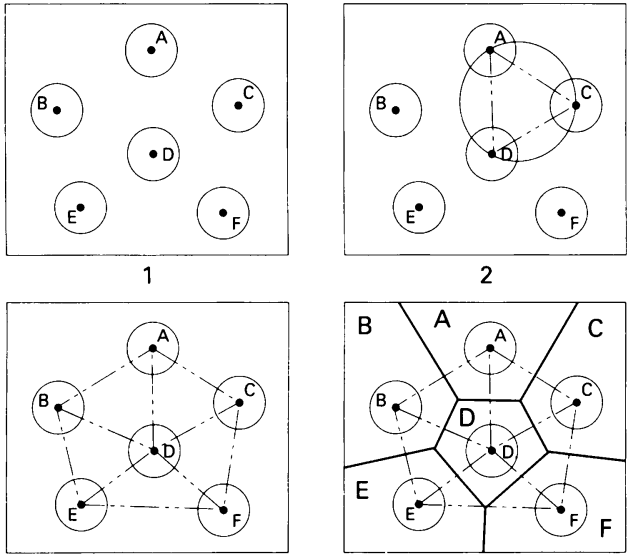

4
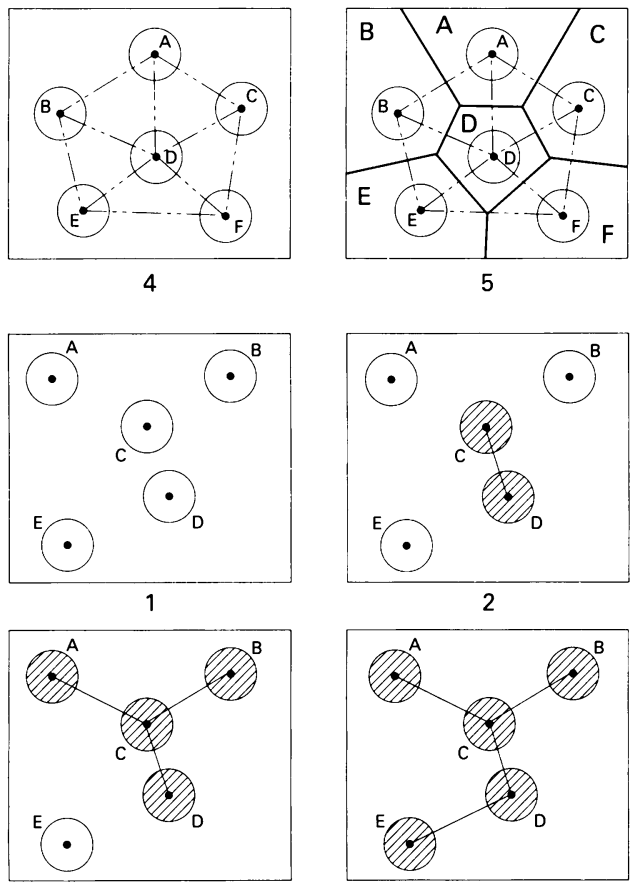

4
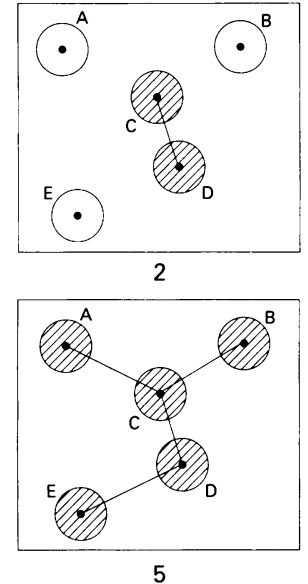

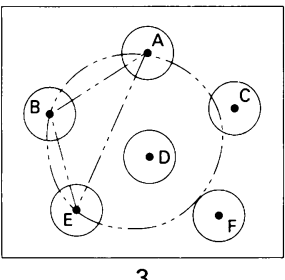

$A, B, C, E, F: 3$ neighbours D: 4 neighbours Length $=A B+A D+A C+B D+B E+$ $C D+C F+D E+D F+E F$ Average line length $=$ length $/ 10$ $\#$ Points $=6$

\# Lines $=10$

Cyclomatic number $=10-6+1=5$ \# Triangles $=5$

Mean cytoplasmic area $=$ (region $A+$ region $B+$ region $C+$
region $D+$ region $E+$ region $F$ ) $/ 6$

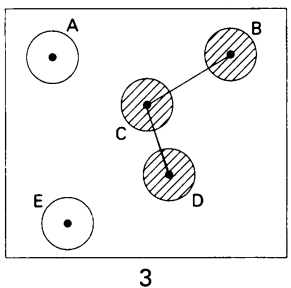

A, B, E: 1 neighbour D: 2 neighbours MST length $=A C+C B+C D+D E$ Average line length $=$ $(A C+C B+C D+D E) / 4$ $\mathrm{Dmin}=\mathrm{CD}$ $D \max =D E$

Figure 5 Top, Schematic explanation of Voronoi's tessellation. Block 1: field containing six nuclei with their centroids marked. Block 2: using Delaunay's triangulation, starting with $A$, a triangle is composed with $A, C$, and $D$. The circumcircle of this triangle does not contain other points than the triangle points, so it is accepted; $D$ and $C$ are neighbours of $A$. Block 3: continuing to find neighbours of $A$, a triangle is composed with $A, B$, and $E$. The circumcircle of this triangle however contains point $D$, so this triangle is not accepted. Block 4: following the same process for all possible triangles for all combinations of points, the triangles drawn have been accepted and the Delaunay graph is complete. Block 5: the complementary tessellation of the Delaunay graph is build by drawing a perpendicular (tessellation) line from the middle of the connecting lines that go in both directions until they touch another tessellation line. At the bottom right, the features drawn from the graph are shown. Besides features based on Delaunay's graph, the artificial mean cytoplasmic area is computed. Bottom, Schematic explanation of the algorithm for building the minimum spanning tree and calculation of spanning tree features. Block 1: field containing five nuclei with their centroids marked. Block 2: after calculating the distances between all the centroids, the distance between $C$ and $D$ has been found to be the shortest, so $C$ and $D$ are connected by a line. Block 3: of the remaining free centroids, $B$ is closest to one of the centroids already connected to the tree, namely $C$, so $B$ and $C$ are connected. Block 4: of the remaining free centroids, $A$ is closest to one of the centroids already connected to the tree, namely $C$, so $A$ and $C$ are connected. Field 5: the last remaining free centroid, $E$, is closest to $D$, so $E$ is taken into the tree by connecting $E$ with $D$. The minimum spanning tree is now completed for this field, and the features calculated from it are shown at the bottom right.

Different histological patterns produce different graphs, and different graphs produce different quantitative data. Syntactic structure has its origin in the graph theory, a geometrical discipline. In chemistry it has been applied to study the configuration of complex molecules. ${ }^{17}$

\section{Counting objects}

Counting objects of interest in tissue sections is a widely applied form of image analysis. Most of the time this concerns counting of proliferation markers in tumours. Greenbough, by 1925 , found that the number of mitoses was associated with survival in breast cancer patients. ${ }^{18}$ A similar observation was made by Grinnell for colorectal cancer in $1939 .{ }^{19}$ Today, mitotic activity in breast cancer, next to lymph node status, remains one of the most important prognostic factors. Moreover, this powerful method in image analysis requires only a microscope and a haematoxylin and eosin stained slide. ${ }^{20}$

It became possible to obtain information on proliferation from interphase nuclei with techniques that, after incubation, introduced labelled nucleotide analogues in the DNA of proliferating cells. Counting the proportion of labelled cells, the labelling index, yielded a reliable measure of the proliferation fraction of a cell population. At first radioactive labels were used, like tritium thymidine labelling. Later, non-isotopic labels such as bromodeoxyuridin (BrDU) became available that could be more easily visualised with antibodies. ${ }^{21}$ In the past decade, antibodies have been raised against proliferation associated antigens such as $\mathrm{Ki} 67$ and proliferating cell nuclear antigen (PCNA). ${ }^{22}{ }^{23}$ In particular the possibility of immunohistochemical detection of $\mathrm{Ki} 67$ in formaldehyde fixed, paraffin wax embedded material was a major improvement. Where traditional counting meets with stereology is the application of point counting methods to score the proportion of immunohistochemically stained nuclei to obtain a highly reliable labelling index; however, this procedure is almost 10 times as fast as the traditional method of counting the number of stained nuclei per 2000 nuclei. ${ }^{24}$

\section{Cytometry and pattern recognition}

Cytometry refers to measuring the amount of a given substance in tissue, cells or nuclei. The observation of hyperchromatism in the nuclei of neoplastic cells, reflecting increased DNA content, is the subjective counterpart of DNA cytometry in everyday pathology. Cytometry depends on the ability to detect the substance of interest by a specific dye and to measure the concentration of that dye. The relation between the concentration of a dye and the optical density of that dye comes from the work of Lambert in 1760 and Beer in 1854. The history of cytometry actually is the history of DNA cytometry. In the late 1890 s, Köhler and Von Rohr at Carl Zeiss in Jena, Germany, developed an ultraviolet microscope to prove Abbe's theory that the use of a lower wavelength would increase the resolution of the microscope. Köhler observed a high absorption at $280 \mathrm{~nm}$ by the chromatin in cells, but believed this resulted from the presence of inorganic substances. It was Caspersson, at the Karolinska hospital in Stockholm, Sweden who attributed this absorption to DNA, or thymonucleic acid, as it was then (fig 6). $\mathrm{He}$ constructed a system for photographic photometry in $1933 .{ }^{25}$ Some years later, the photographic detection system was replaced by a photoelectric spectrophotometric system, followed by photomultipliers. These were very precise and well suited for high resolution analysis of intracellular structures, but not very fast. However, fed by the growing interest in cancer research, and the observations by Caspersson, Pollister, Mellors, Leuchtenberger, Richards, Atkin, and several others, that tumour cells and normal cells differed in their 


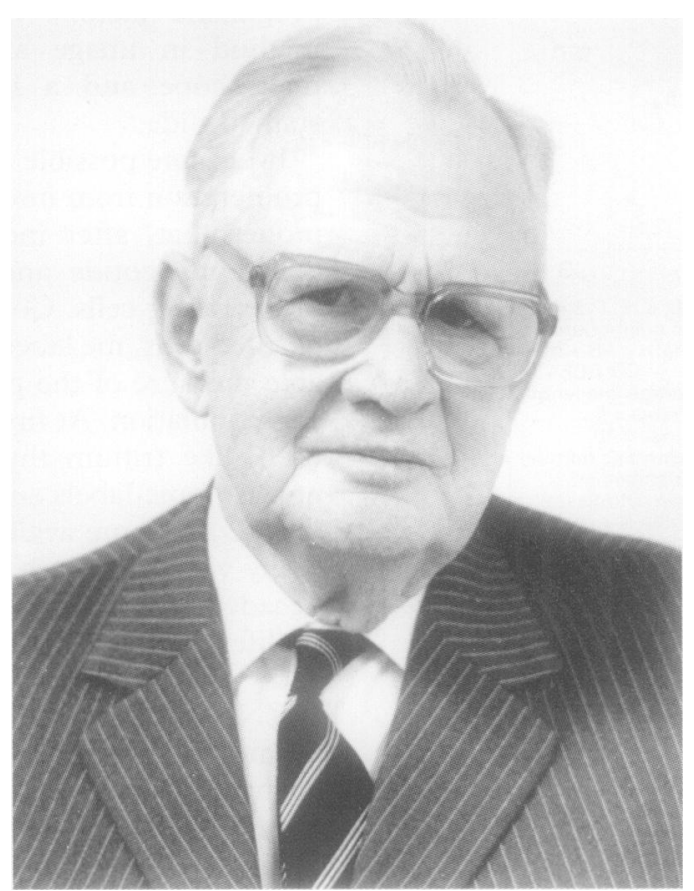

Figure 6 Professor T Caspersson who was the first to apply DNA cytometry in the 1930s, at the Karolinska Hospital in Stockholm, Sweden. (Courtesy of the Department of Pathology, Karolinska Hospital, Stockholm.)

DNA content, systems were sought that could easily measure the total amount of DNA per cell in a large number of cells. ${ }^{26}$

Meanwhile, DNA cytometry using visible light emerged. By 1933, Mainland had estimated the amount of haematoxylin in cervical normal and tumour cells. ${ }^{27}$ However, haematoxylin is not a stoichiometric stain for DNA, contrary to the Feulgen reaction discovered by Feulgen and Rossenbeck in $1924{ }^{28}$ This Feulgen staining proved to be specific for DNA, and the amount of stain was proportional to the amount of DNA present. Pollister and Ris, in 1948 , built the first prototype of a simple microphotometer using a microscope equipped with a photomultiplier and a galvanometer to measure the output current. ${ }^{29}$ Also in 1948, Ris and Mirsky measured the total amount of DNA in a nucleus and Swift, in 1950, demonstrated the doubling of DNA prior to mitosis. $^{3031}$ In the years to follow, scanning microscopes were introduced to cope with inhomogeneities in the staining intensity within nuclei. Moreover, these developments led to systems that were able to measure large

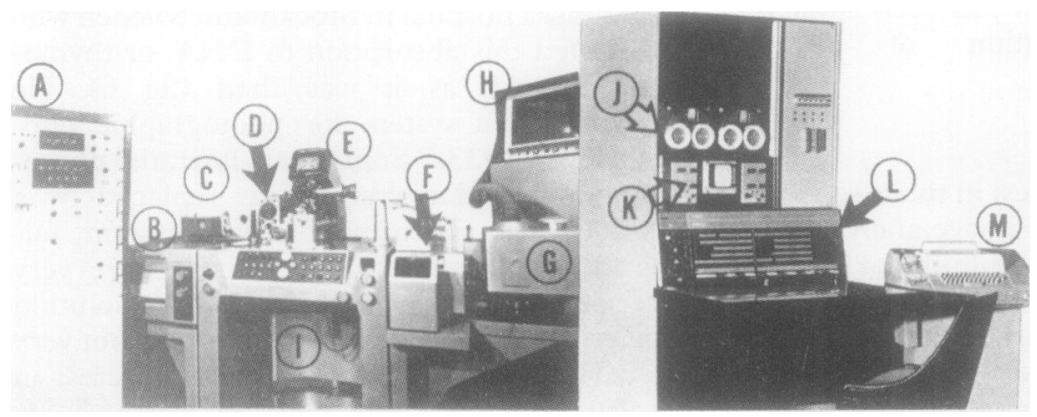

Figure 7 The Taxonomic Intra-cellular Analytic System (TICAS) developed by Wied et al in the 1960s is an example of one of the first computer based image cytometry systems. The system is composed of a microphotospectrometer $(A-I)$ connected to a computer $(\mathcal{F}-M)$. (Reprinted with permission of Dr GL Wied.) numbers of cells. One of the first of such systems was the cytoanalyser of Tolles et al based on a scanning microscope. ${ }^{32}$ This group, in 1961 , reported a study on 700 cervical and vaginal smears in which they measured the DNA content of 200 cells each. ${ }^{33} 34$

The introduction of computers has been a major influence on the evolution of image analysis. In addition to enhanced measuring performance, the use of computers has stimulated the development of systems for automatic cell classification based on pattern recognition. In 1961 a system was designed for the automatic recognition of binucleated lymphocytes. ${ }^{35}$ Some years later, systems followed by Prewitt and Mendelsohn, and Wied et al (fig 7). ${ }^{36}{ }^{37}$ At present, systems for automatic classification of cells have been developed that are used-for example, for prescreening of Pap smears, and quality control. ${ }^{38}$ Furthermore, systems have been developed capable of automatic recognition of mitoses in tissue sections. $^{39}$

Computer based pattern recognition also stimulated the analysis of chromatin texture in cell nuclei. ${ }^{40}$ Coarseness of chromatin is a feature widely used in the routine assessment of nuclear atypia. However, by means of high resolution image analysis, even in apparently normal uterine cervix cells next to cervical neoplasia, chromatin texture changes can be detected. ${ }^{41}$ These malignancy associated changes, therefore, may be useful in screening for cervical neoplasia.

DNA cytometry as research tool and in clinical application was stimulated by the development of the computer based flow cytometer in the early 1960 s by Kamentsky et $a_{l}{ }^{42}$ Flow cytometers enabled the measurement of the DNA content in thousands of cells, and produced DNA histograms as we now know them. With time, however, image cytometry systems, thanks to the enormous progression of computer technique, could cope with an increasing number of cells. Modern DNA image cytometry systems can measure thousands of cells within minutes and produce histograms like those from DNA flow cytometry systems. At present, due to the ongoing fall of prices of computer hardware with a concurrent increase in performance, and the availability of inexpensive high quality video cameras for recording the images, DNA image cytometry systems have come within the reach of any modern pathology laboratory.

DNA cytometry measures the total amount of DNA per nucleus. For this there are two prerequisites. First, the complete nucleus needs to be present in the image. This condition in general is easily met in cytological specimens, but not in standard $4 \mu \mathrm{m}$ tissue sections. Second, the nucleus must be discriminated from its environment to recognise it as only one nucleus. This discrimination, or segmentation, is easy when cells are loosely dispersed but difficult when nuclei are overlapping, as in thick cytological specimens and tissue sections. Against this background it is clear why many of the early studies of DNA cytometry in tumours focused on cervical 
smears. ${ }^{27} 33$ Later, cytological specimens of disaggregated fresh frozen tissue were also used, ${ }^{43}$ and a tremendous step forward was made by Hedley et al who developed a method to disaggregate paraffin wax embedded material to cell suspensions. ${ }^{44}$ This discovery disclosed archival material as a source for DNA cytometry, and greatly increased the opportunities to study the clinical value of DNA cytometry in retrospective studies.

However, it was felt that the possibility to measure the DNA content of cells in tissue sections could help to integrate DNA cytometric features with histomorphological information, so this issue was still tempting. Successful attempts in this area have been reported for carcinomas in which generally there is little overlap of nuclei such as renal cell cancer and prostate cancer. ${ }^{45}{ }^{46}$ In addition, correction formulas have been proposed to cope with incomplete nuclei due to sectioning. ${ }^{47}$ Recently, the importance of a very strict measurement protocol has been emphasised to obtain reliable results by DNA cytometry in thin tissue sections. ${ }^{48}$ Another approach to avoid problems with incomplete cells because of section thickness has been to measure the DNA content in three dimensional reconstructions of tissue, based on confocal laser scanning microscopy in thick tissue sections with advanced image processing. ${ }^{49}$

While DNA cytometry measures the genetic alterations in tumours as a change in the total amount of DNA, recently a new techniquecomparative genomic hybridisation (CGH)has been developed that measures in one experiment the genetic changes (gain or loss of DNA) at the level of individual chromosomes, using digital image analysis. ${ }^{50}$ In this procedure DNA isolated from tumour specimens is labelled with a green fluorochrome and mixed with red labelled DNA obtained from cells with a normal diploid chromosome complement. The mixture is hybridised to normal metaphase preparations. Hybridised test and control DNA sequences compete in the annealing process for their complementary spots on the individual chromosomes, and are recognised via the different fluorochromes. The ratio of green to red fluorescence for each chromosomal region is a measure of the under or overrepresentation of genetic material for that region in the tumour studied. In this sense, $\mathrm{CGH}$ can be regarded as a refinement of DNA cytometry and, currently, research groups all over world are employing this method to study its clinical relevance in tumour pathology. ${ }^{52}$

Image cytometry is also used to measure the amount of immunohistochemically stained proteins in cells such as oestrogen receptors in breast cancer. ${ }^{53}$ At first sight this procedure may closely resemble DNA image cytometry but fundamental differences exist. While Feulgen staining of DNA is stoichiometric, immunohistochemical staining of antigens is not; the amount of staining is not proportional to the amount of antigen present and is influenced by many factors. Therefore, immunoquantitation by image analysis in any case requires calibration of the staining result by using a specimen with a known amount of antigen, and tissue processing is critical.

For the many cases in which one wants to assess the proportion of cells positive for an immunohistochemical staining, rather than the exact distribution of staining intensities over the cells, a point counting procedure could be much more powerful.

This brief overview of the origins of image analysis in pathology inevitably cannot be comprehensive as the evolution in this field of science has been tremendous. For example, developments in the area of tissue handling and sampling have not been addressed. ${ }^{54-57}$ For the wide range of established clinical applications we refer to the recent textbooks on this topic. $^{458}$

The help of the photographers from the Antoni van Leeuwenhoek Hospital, Amsterdam, The Netherlands, and from the Department of Pathology, Karolinska Hospital, Stockholm Sweden in providing figures 1 and 6 is gratefully acknowledged.

Schierbeek A. Antoni van Leeuwenhoek, zijn leven en zijn werken. Vol 1. Lochem: De Tijdstroom, 1950:110.

Charnsangavej C. New imaging modalities for follow-up of colorectal carcinoma. Cancer 1993;71:4236-40.

3 Leeuwenhoek A. Microscopical observations concerning blood etc. Phil Trans 1674;9:121.

4 Baak JPA, ed. Manual of quantitative pathology in cancer diagnosis and prognosis. Heidelberg: Springer-Verlag, 1991.

5 Buffon G. Essai d'arithmetique morale. Suppl a l'Histoire Naturelle (Paris), 1777.

6 Delesse A. Procidé mechanique pour determiner la composition des roches. Ann Mines (IV) 1847;13:379.

7 Rosiwal A. Über geometrische Gesteinsanalysen. Ein einfacher Weg zur ziffermäßigen Feststellung der Quantitätsverhältniss der Mineralbestandteile gemengter Gesteine. Wien: Verhandlangen der KK Geologischen Reichsanstalt, 1898;143:5-6.

8 Glagolev AA. On the geometrical methods of quantitative mineralogic analysis of rocks. Transcripts of Institute Economic Mineralogy and Metallurgy, Moscow 1933;59:1.

9 Chalkey HW. Method for quantitative morphological analysis of tissues. F Natl Cancer Inst 1943;4:47-53.

10 Weibel ER. Stereological methods. Vol 1: Practical methods for biological morphometry. London: Academic Press, 1979.

11 Gundersen HJG, Jensen EB. Stereological estimation of the volume weigthed mean volume of arbitrary particles volume weigthed mean volume of arbitrary particles
observed on random sections. $\mathcal{f}$ Microsc $1985 ; 138: 127-42$.

12 Donné A. Cours de Microscopie Complémentaire des Etudes Médicales: Anatomie Microscopique et Physiologie des Fluides de l'Economie: Atlas Executé d'Apres Nature au MicroscopeDaguerréotype. Paris: Ballière, 1845.

13 Jacobj W. Über das rhyrmische Wachstum der Zellen durch Verdoppelung ihres Volumens. Arch Entwickl 1925;106: 124-92.

14 Haumeder E. Vergleichende Kern- und Nukleolenmessungen an verscheidenen Organengeweben mit besonderer gen an verscheidenen Organengeweben mit besonderer Berücksichtigung der malignen

15 Schairer E. Kernmessungen und Chromosomenzahlung an menschlichen Geschwulsten. Zeitschrift für Krebsforschung 1935;43:1-38.

16 Ehrich WE. Nuclear sizes in growth disturbances with special reference to the tumor cell nuclei. Am $\mathcal{f} M e d S c i 1936$ 192:772-90.

17 Diest PJ van, Kayser K, Meijer GA, Baak JPA. Syntactic structure analysis. Pathologica 1995;87:255-66.

18 Greenbough RB. Varying degrees of malignancy in cancer of the breast. Cancer Res 1925;9:452-63.

19 Grinnell RS. The grading and prognosis of carcinoma of the colon and rectum. Ann Surg 1939;109:500-33.

20 Baak JPA, van Dop H, Kurver PHJ, Hermans J. The value of Baak JPA, van Dop H, Kurver PHJ, Hermans J. The value of
morphometry to classic prognosticators in breast cancer. Cancer 1985;56:374-82.

21 Gratzner HG. Monoclonal antibody to 5-bromo- and 5-iododeoxy-uridine: a new reagent for detection of DNA replication. Science 1982;218:474-5

22 Howell WM, Black DA. Controlled silver staining of nucleolus organizer regions with a protective colloida developer: a one step method Experientia 1980;36:1014.

23 Gerdes J, Schwab U, Lemke H, Stein $H$. Production of mouse monoclonal antibody reactive with a human nuclear mouse moclonal antibody reactive with a human nuclear 1983;31:13-20.

24 Polkowski W, Baak JPA, Lauschot JJB von, Meijer GA Schuurmans LT. et al. Reproducibility of p53 and Ki67 Schuurmans LT. et al. Reproducibility of p53 and Ki67
immunoquantitation in Barret's oesophagus. Anal Quant Cytol Histol. [In press.]

25 Casperson TO. History of the development of cytophotometry from 1935 to the present. Anal Quant Cytol Histo 1987;9:2-6.

26 Bartels PH. Quantitation in histopathology. Objectives, origins, digital image analysis, and unresolved issues. In Marchevsky AM, Bartels PH, eds. Image analysis: $A$ prime for pathologists. New York: Raven Press, 1994. 
27 Mainland D Colorimetric tests of nuclear staining. Stain Technology 1933;8:69-72.

28 Feulgen R, Rossenbeck H. Mikroskopisch-chemischer Nachweis einer Nukleinsäure vom Typus der Thymonukleinsäure und die darauf beruhende Elektiv Färbung von Zellkernen in microskopischen Präparaten. $Z$ Physiol Chem 1924;135:203-48.

29 Pollister AW, Ris H. Nucleoprotein determinations in cytological preparations. Quant Biol 1948;12:147-57.

30 Ris H, Mirsky AE. Quantitative cytochemical determination of desoxyribonucleic acid with the Feulgen nucleal reaction. I Gen Physiol 1949;33:125-46.

31 Swift $\mathrm{H}$. The desoxyribose nucleic acid content of animal nuclei. Physiol Zool 1950;23:169-98.

32 Koss LG. Analytical quantitative cytology. A historical perspective. Anal Quant Cytol Histol 1982;4:251-6.

33 Tolles WE, Horvath WJ, Bostrom RC. A study of the quantitative characteristics of the exfoliated cells from the female genital tract: I. Measurement methods and results. Cancer 1961;14:437-54.

34 Tolles WE, Horvath WJ, Bostrom RC. A study of the quantitative characteristics of the exfoliated cells from the female genital tract: II Suitability of quantitative cytologifemale genital cal measurements for automatic prescreening. Cancer 1961;14:455-68.

35 Preston K. The Cellscan system: A leukocyte pattern analyzer. Proc Western foint Comput Conference 1961:173.

36 Prewitt JMS, Mendelsohn ML. The analysis of cell images Ann NY Acad Sci 1966;128:1035-53.

37 Wied GL, Bartels PH, Oldfield DG. Taxonomic intracellular analytic system (TICAS) for cell identification. Acta Cytol 1968;12:177-210.

38 Mango LJ. Computer-assisted cervical cancer screening using neural networks. Cancer Letters 1994;77:155-62.

39 Kate TK ten, Beliën JAM, Smeulders AWM, Baak JPA Method for counting mitoses by image processing in Feulgen stained breast cancer sections. Cytometry 1993;14:24150 .

40 Doudkine A, Macaulay C, Poulin N, Palcic B. Nuclear texture measurements in image cytometry. Pathologica 1995 87:286-99.

41 Guillaud M, Doudkine A, Garner D, MacAulay C, Palcic B. Malignancy associated changes in cervical smears: systematic changes cytometric features with the grade of dysplasia. Anal Cell Pathol 1995;9:191-204.

42 Kamentsky LA, Melamed MR, Derman H Spectrophotometer: new instrument for ultrarapid cell Spectrophotometer: new instrume
analysis. Science 1965;150:630-1.

43 Vindelov L. Flow microfluorometric analysis of nuclear DNA in cell suspensions. Virchows Arch B Cell Pathol 1977; 24:227-42.

44 Hedley DW, Friedlander ML, Taylor IW, Rugg CA Musgrove EA. Method for analysis of cellular DNA content of paraffin-embedded pathological material using flow cytometry. $\mathcal{F}$ Histochem Cytochem 1983;31:1333-5.
45 Bennington JL, Mayall BH. DNA cytometry on fourBennington JL, Mayall BH. DNA cytometry on fourmicrometer sections of paraffin embedded

46 Greene DR, Taylor SR, Wheeler TM, Seardino PT. DNA ploidy by image analysis of individual foci of prostate cancer: a preliminary report. Cancer Res 1991;51:4084-9.

47 Haroske G, Dimmer V, Hermann WR, Kunze KD, Meye W. Metastasising APUD cell tumours of the human gastrointestinal tract. Light microscopic and karyometric studies. Pathol Res Pract 1984;78:363-8.

48 Williams RA, Baak JPA, Meijer GA, Charlton IG. Further testing of the value of a measurement protocol for DNA ploidy studies using image cytometry: Comparison of results obtained from cytologic and paraffin section preparations. Anal Quant Cytol Histol 1996;18:345-50.

49 Zhu Q, Tekola P, Baak JPA, Beliën JAM. Measurement by confocal laser scanning microscopy of the volume of epidermal nuclei in thick skin sections. Anal Quant Cyto Histol 1994;16:145-52.

50 Kallioniemi A, Kallioniemi OP, Sudar D, Rutovitz D, Gray JW, Waldman F, et al. Comparative genomic hybridization for molecular cytogenetic analysis of solid tumors. Science 1992;258:818-21.

51 Manoir S du, Speicher MR, Joos S, Schrock E, Popp S, Dohner $\mathrm{H}$, et al. Detection of complete and partial chromosome gains and losses by comparative genomic in situ hybridization. Hum Genet 1993;90:590-610

52 Hermsen MAJA, Meijer GA, Baak JPA, Joenje $H$, Walboomers JJM. Comparative genomic hybridization: a new tool in cancer pathology. Hum Pathol 1996;27:342-9.

53 Colley M, Kommoss F, Bibbo M, Dytch HE, Franklin WA Holt JA, et al. Assessment of hormone receptors in breast carcinoma by immunohistochemistry and image analysis. II Estrogen receptors. Anal Quant Cytol Histol 1989;11 307-14.

54 Baak JPA, Noteboom E, Koevoets JJM. The influence of fixatives and other variations in tissue processing on nuclear morphometrical features. Anal Quant Cytol Histol 1989;11:219-24

55 Bergers E, Jannink I, Diest PJ van, Cuesta MA, Meijer S, Mourik JC van, et al. The influence of fixation delay on mitotic activity and flow cytometric cell cycle variables. Hum Pathol 1997;28:95-100.

56 Gundersen HJG, Osterby R. Optimizing sampling efficiency of stereological studies in biology: or "do more less well!" 7 Microsc 1981;121:65-73.

57 Fleege JC, Diest PJ van, Baak JPA. Systematic random sampling for selective interactive nuclear morphometry in breast cancer sections. Refinement and multiobserver breast cancer sections. Refinement and 15:281-9.

58 Hamilton PW, Allen DC, eds. Quantitative clinical pathology. Oxford: Blackwell Scientific Publications, 1995

59 Bouw GM. Growth and growth retardation of the human placenta. PhD Thesis, Free University, Amsterdam, The Netherlands. 